\title{
NILAI MORAL DALAM ANTOLOGI CERPEN KARYA MAHASISWA PGSD ANGKATAN 2013 UNIVERSITAS PGRI ADI BUANA SURABAYA
}

\author{
Pana Pramulia \\ Program Studi Guru Sekolah Dasar \\ Universitas PGRI Adi Buana Surabaya \\ panapramulia@gmail.com
}

\begin{abstract}
ABSTRAK
Nilai merupakan persoalan universal yang dimiliki seluruh manusia. Setiap manusia mempunyai kecenderungan terhadap nilai. Maksudnya, setiap orang akan cenderung berorientasi kepada kebaikan-kebaikan. Kebaikan yang dimiliki atau dilakukan manusia merupakan nilai dari sebuah kehidupan. Begitu juga dengan mahasiswa PGSD Universitas PGRI Adi Buana Surabaya. Cerpen mereka yang terkumpul dalam antologi Balada Rasa dan Cerita menyuguhkan nilai-nilai hidup yang baik. Berdasarkan pembacaan intensif, setiap cerpen menguraikan mengenai nilai moral tokoh beserta dampaknya. Selain itu, juga menceritakan bahwa angkara murka pasti mengalami kerugian yang besar. Nilai moral tersebut mewarnai hampir seluruh cerpen yang secara keseluruhan berjumlah tiga puluh. Maka dari itu, untuk memaparkan nilai moral antologi cerpen tersebut digunakan pendekatan pragmatik. Berdasarkan analisis, nilai moral yang diungkapkan berasal dari realitas pengalaman para penulis yang mencermati kehidupan sekitarnya, walaupun cerita yang disampaikan sudah diubah menjadi bentuk fiksi.
\end{abstract}

Kata Kunci: Nilai moral, Antologi Cerpen, Balada Rasa dan Cerita, Mahasiswa PGSD.

\section{Pendahuluan}

Setiap manusia mempunyai kesadaran berbuat baik untuk menjalani kehidupan. Siapapun akan memiliki keinginan untuk diperlakukan baik. Kesadaran berbuat baik dan keinginan diperlakukan baik itulah yang mendorong manusia berorientasi kepada nilai-nilai hidup. Nilai merupakan persoalan universal dalam peradaban manusia di dunia. Semua manusia di belahan dunia manapun mengakui bahwa kebaiakan akan selalu menentramkan dan angkara murka pasti akan menimbulkan kerusakan. Hal tersebut dalam kebudayaan manusia biasa disebut filosofi kehidupan.

Pramulia (2017:37) menyatakan filosofi dalam sebuah kebudayaan memuat nilai-nilai yang merupakan hasil dari perbuatan atau perilaku manusia. Maka, untuk mengetahui nilai-nilai yang terdapat dalam kebudayaan manusia, seseorang butuh pengamatan dan perenungan yang mendalam. Tujuannya, agar setiap manusia dapat mengimplementasikan nilai-nilai yang di dapat dalam menjalani kehidupan sehari-hari. Di sisi lain, seseorang dapat mencari nilai-nilai hidup di dalam cerita-cerita leluhur atau dari hasil membaca karya-karya tulisan orang lain.

Penanaman nilai hendaknya dilakukan ketika manusia masih anak-anak. Nilai yang tertanam dalam diri anak-anak akan tersimpan di otak bawah sadar, sehingga akan menjadi bekal pada kehidupannya kelak. Nilai-nilai tersebut akan dapat beraksi positif ketika manusia mendapatkan reaksi, baik dari dalam diri maupun dari luar dirinya. Itulah yang disebut sebagai benteng pertahanan manusia. 
Penanaman nilai bisa menggunakan media beragam, misalnya dengan menggunakan karya sastra. Karya sastra, seperti cerpen banyak memuat nilai - dalam hal ini nilai moral sebagai pembelajaran kepada siapapun.

Karya sastra identik dengan keindahan yang pada dasarnya keindahan tersebut dibutuhkan oleh setiap manusia. Frondizi (2011:1 - 2) menyatakan keindahan merupakan perwujudan cara pandang yang khas terhadap dunia. Cara pandang tersebut biasa dikatakan sebagai nilai. Keindahan di dalamnya terdapat kebaikan dan kebenaran, sehingga kecenderungan manusia terhadap keindahan begitu kuat. Maka dari itu, penelitian ini menggunakan cerpen hasil karya mahasiswa PGSD angkatan 2013 Universitas Adi Buana Surabaya untuk membongkar nilai moral yang terdapat di dalamnya.

Cerpen-cerpen karya mahasiswa PGSD angkatan 2013 tersebut bisa dikatakan sebagai sastra anak, karena orientasi para penulis kelak akan menjadi guru di sekolah dasar. Sastra anak merupakan sastra yang dibaca anak-anak yang ditulis oleh orang dewasa (Sarumpaet, 2010:2). Selain itu, nilai-nilai yang terdapat dalam karya mereka identik dengan kehidupan sehari-hari anak. Nilai yang terdapat dalam antologi cerpen banyak menguraikan nilai-nilai moral tokohnya. Moral merupakan dasar dari seluruh perilaku manusia. Teew (2013:51) menyatakan sebuah masalah yang tidak bisa dihindari dalam penelitian sastra, yaitu masalah nilai.

Seperti yang disebutkan sebelumnya, bahwa kecenderungan manusia terhadap nilai begitu kuat, termasuk nilai moral. Moral seseorang diperoleh dari pengalaman moral atau pengalaman kebaikan yang dialaminya. Held (1991:275-276) menyatakan pengalaman moral merupakan pengalaman memilih secara sadar, menerima atau menolak secara sukarela atas kemauan sendiri. Artinya, sejak kecil seseorang dibebaskan mengambil keputusan untuk merenungkan kembali kejadian-kejadian, baik kejadian baik maupun buruk. Hasil dari perenungan tersebut akan berdampak pada perilaku sehari-hari. Berdasarkan hal tersebut, seseorang dapat dilihat memiliki nilai moral atau tidak.

Nilai moral yang disampaikan para penulis cerpen antologi Balada Rasa dan Cerita tentu memiliki modal nilai moral yang telah tersimpan di otak bawah sadarnya. Selain itu, sebagai calon guru sekolah dasar para penulis cenderung memasukkan nilai-nilai moral dalam cerpen mereka. Nilai moral tersebut dapat digunakan untuk menanamkan nilai-nilai moral kepada siswa sekolah dasar, karena beberapa cerpen memiliki nuansa legenda dan dongeng yang memang tepat untuk usia anak sekolah dasar.

Berdasarkan uraian di atas, penelitian ini mempunyai tujuan mendeskripsikan nilai moral dalam antologi cerpen mahasiswa PGSD angkatan 2013 Universitas Adi Buana Surabaya. Manfaat dari penelitian ini, yaitu manfaat teoretis mengetahui nilai moral dalam antologi cerpen mahasiswa PGSD angkatan 2013 Universitas Adi Buana Surabaya, dan manfaat praktis penelitian ini dapat digunakan sebagai acuan penggalian nilai moral di dalam karya sastra lainnya.

\section{Metode Penelitian}


Penelitian ini menggunakan pendekatan pragmatik untuk mengetahui, memahami, dan sebagai pijakan analisis terhadap nilai moral yang terdapat dalam cerpen. Pendekatan pragmatik merupakan pendekatan membaca teks untuk mencari simbol-simbol dan atau nilai-nilai dalam sebuah teks yang berkaitan dengan kebudayaan masyarakatnya.

Metode pemerolehan data yang digunakan ada dua teknik. Pertama, membaca keseluruhan sumber data, yaitu antologi cerpen Balada Rasa dan Cerita karya mahasiswa PGSD angkatan 2013 Universitas PGRI Adi Buana Surabaya. Cerpen yang terdapat dalam antologi tersebut berjumlah tiga puluh cerpen. Kedua, peneliti menyeleksi sumber data yang dikaitkan dengan kerangka teori yang digunakan, yaitu nilai moral. Setelah melakukan seleksi, peneliti menentukan sepuluh cerpen yang akan dianalisis. Alasan memilih sepuluh cerpen, karena dapat mewakili keseluruhan cerpen.

Teknik analisis data yang digunakan, yaitu teknik tekstual. Teks berasal dari sepuluh cerpen hasil seleksi yang sudah dikaitkan dengan kerangka teori, yaitu nilai moral. Langkah-langkah analisis data mencakup interpretasi, eksplanasi, dan deskripsi.

\section{Hasil dan Pembahasan}

Sepuluh cerpen yang sudah dipilih, antara lain Diary karya Islamidinah, Dua Sisi karya Eky Dimas Yuliati, Hargai Hidupmu Kawan karya Luluk Azmy Mahaq, Syal Untuk Kakek karya Aini Nur Habibah, Pesan Dari Ibu karya Veni Anggreni, Kenangan yang Terlampau karya Endah Wahyu, Anak Gembala Pembohong dan Serigala karya Ilham Falah, Kado Istimewa karya Ria Desy Fatmawati, Kenapa Kita Harus Pintar karya Siti Zauziah Farida, dan Keikhlasan Hati karya Noveni Putri.

Setelah melalui pembacaan intensif terhadap tiga puluh cerpen, maka sepuluh novel tersebut dianggap dapat mewakili cerpen secara keseluruhan. Hal tersebut disebabkan, antara satu novel dengan novel lainnya mempunyai kesamaan substansi dalam menguraikan nilai-nilai moral. Hanya, setting, alur, penokohan, dan redaksionalnya yang berbeda. Di sisi lain, tema yang diusung hampir sama, yaitu berupa nasihat-nasihat bijak kepada para tokoh dan atau para pembacanya.

Berdasarkan tema yang menguraikan nasihat bijak tersebut, pembaca dapat menemukan nilai moral dari tokoh dalam memaknai peristiwa maupun keadaan yang dialaminya. Nasihat bijak yang terdapat dalam cerpen ada yang diuraikan berupa wacana. Maksudnya, di dalam wacana terdapat nasihat yang ditujukan kepada pembaca. Selain itu, ada yang diuraikan tokoh untuk menasihati tokoh lain dan juga untuk para pembaca. Berikut kutipannya.

"Diana sahabatku tersayang. Kan nggak semua masalah itu harus di umbar di media sosial. Itu sama saja membuka aib sendiri. Apa nggak malu kalo banyak orang yang tau? Kalo aku pasti malu, Di. Bukankah Masalahmu itu seperti Auratmu bukan untuk di umbar dan dijadikan konsumsi Publik (Islamidinah dalam Diary, 2017:99).

Berdasarkan kutipan di atas, tokoh aku berusaha memberi nasihat kepada tokoh Diana yang berperilaku berlebihan dalam menggunakan media sosial. Diana seringkali menceritakan persoalan 
hidupnya di media sosial miliknya. Padahal menurut tokoh aku, persoalan sama halnya dengan aurat yang harus dijaga. Nasihat tokoh aku tersebut sebenarnya tidak hanya untuk Diana, melainkan juga untuk para pembaca yang dewasa ini seringkali berperilaku serupa. Dari sini, nilai moral dapat ditemukan pada nasihat tokoh aku kepada Diana. Tokoh aku dapat membedakan pentingnya menggunakan media sosial dengan bijaksana.

Nilai moral, seperti yang sudah diuraikan sebelumnya harus ditanamkan sejak dini kepada anakanak. Wacana atau contoh perilaku baik hendaknya senantiasa ditularkan kepada anak-anak. Tujuannya agar nilai moral tersebut tersimpan dalam otak bawah sadar sebagai modal menghadapi kehidupan. Berikut kutipannya.

Pukul 07.00 anak-anak segera masuk ke kelas II A. Kimmy memimpin teman-temannya untuk berbaris dan periksa kerapian. Setelah selesai semuanya masuk ke kelas. (Eky Dimas Yuliati dalam Dua Sisi, 2017:102).

Uraian wacana Eky Dimas Yuliati dalam cerpen Dua Sisi tersebut merupakan gambaran kedisiplinan yang dilakukan siswa-siswa SD kelas II. Kedisiplinan merupakan salah satu sisi dari kebaikan yang memang seharusnya ditanamkan sejak dini kepada anak-anak. Selain itu, dalam kutipan tersebut tokoh Kimmy bertugas memimpin teman-temannya berbaris. Hal tersebut menggambarkan nilai moral yang dimiliki oleh siswa-siswa SD kelas II. Harapannya, perilaku siswa-siswa yang digambarkan dapat menular kepada anak-anak di dunia nyata jika cerpen Dua Sisi dibacakan. Paling tidak pembaca atau pendengar dapat termotivasi untuk menengok kekurangan dan kelemahan dirinya, sehingga mampu mengoreksi perilakunya sendiri.

Segera timbul kesadaran baru. "Aku manusia masih muda, kuat, dan sehat. Tidak pantas aku melenyapkan kehidupanku sendiri. Mulai sekarang, aku harus punya cita-cita dan akan bekerja dengan baik untuk bisa pula bermanfaat bagi makhluk lain". (Luluk Azmy Mahaq dalam Hargai Hidupmu Kawan, 2017:110).

Kutipan di atas menggambarkan dialog tokoh dengan dirinya sendiri. Tokoh aku sadar akan kekurangan dan kelemahannya, sehingga ada ucapan janji setelahnya. Nilai moralnya, tokoh aku dengan jujur mengakui kekurangannya dan mempunyai niat untuk dapat bermanfaat bagi makhluk lain. Berarti bukan hanya manusia yang menjadi tujuan kebaikannya, tetapi juga seluruh makhluk yang terdapat di alam raya ini. Itulah yang disebut nilai moral ketika seseorang mampu bermanfaat untuk sesamanya atau paling tidak untuk orang-orang yang dikasihinya.

Ketika presentasi di kelas Sandra bercerita bahwa syal ini untuk orang tersayang yaitu kakeknya, agar kakek tidak kedinginan ketika ingin berjalan-jalan di sekitar rumah. (Aini Nur Habibah dalam Syal Untuk Kakek, 2017:133).

Seperti yang dijelaskan sebelumnya, bahwa kebermanfaatan kepada orang lain begitu penting dalam kehidupan manusia. Jika belum bisa bermanfaat untuk semua orang paling tidak untuk orang-orang terdekat. Kutipan di atas menggambarkan hal tersebut, dimana tokoh Sandra berkeinginan untuk 
membahagiakan kakeknya. Dalam kutipan diuraikan "agar kakek tidak kedinginan" merupakan luapan kasih sayang cucu kepada kakeknya. Bentuk nilai moral, salah satunya ada rasa kasih sayang di dalamnya. Dari kasih sayang itulah muncul kepatuhan dan penghormatan kepada orang yang disayangi.

"Kak, saya mohon maaf. Jangan marah ya. Ibu saya mengajarkan kepada saya untuk mendapatkan uang dari usaha berjualan atas jerih payah sendiri, bukan dari mengemis". (Veni Anggreni dalam Pesan Dari Ibu, 2017:151).

Kutipan di atas mencerminkan kepatuhan anak kepada orang tua. Kepatuhan dapat terlaksana ketika terdapat kasih sayang di dalamnya. Kutipan tersebut juga menjelaskan nilai moral yang ditanamkan ibu kepada anaknya, bahwa usaha sendiri lebih baik daripada mengemis/meminta-minta. Nilai moral tersebut diharapkan dapat menular kepada pembaca, khususnya anak-anak dan remaja. Selain itu, nilai moral juga terdapat pada sikap yang teguh dari tokoh saya kepada kebaikan.

Nilai moral juga tergambar dalam diri tokoh yang menyadari kesalahan sekaligus mengungkapkan janji tidak akan mengulanginya kembali. Gambaran tersebut terdapat dalam cerpen Kenangan yang Terlampau karya Endah Wahyu. Berikut kutipannya.

Persahabatan kami lebih berharga daripada kalung itu. Yunita benar-benar menyesal dengan perbuatannya. Aku berjanji tak akan membenarkannya peristiwa ini berulang kembali. (Endah Wahyu dalam Kenangan yang Terlampau, 2017:157).

Kutipan di atas menjelaskan penyesalan tokoh aku akan kesalahannya. Selain mengakui kesalahan, tokoh aku juga berjanji tidak akan mengulanginya lagi, walaupun redaksi kutipan "Aku berjanji tak akan membenarkannya peristiwa ini berulang kembali". Nilai moral juga terdapat pada pentingnya persahabatan daripada sebuah benda, yaitu kalung. Padahal, dewasa ini banyak sekali ditemui manusia lebih mementingkan materi atau dirinya sendiri daripada persahabatan dan persaudaraan.

Bentuk lainnya dari nilai moral adalah kejujuran. Manusia dituntut untuk jujur agar tidak terjadi perselisihan dalam kehidupan bermasyarakat. Sedangkan kebohongan akan mengakibatkan perselisihan dan merugikan diri sendiri maupun orang lain. Cerpen Anak Gembala Pembohong dan Serigala karya Ilham Falah memaparkan hal demikian. Berikut kutipannya.

"Jangan pernah sekali-kali kamu berbohong. Karena sekali kamu berbohong, maka tak ada yang akan percaya lagi pada kata-katamu. Meskipun pada waktu itu kamu berkata jujur. (Ilham Falah dalam Anak Gembala Pembohong dan Serigala, 2017:161).

Kutipan di atas menegaskan bahwa kebohongan akan mengakibatkan kerugian terhadap diri sendiri. Kutipan tersebut selain merupakan nasihat kepada tokoh dalam cerpen, juga nasihat kepada pembaca. Penulis cerpen berpesan, bahwa sekali saja manusia berbohong, maka selanjutnya akan sulit sekali dipercaya. Walaupun tidak menyebutkan pentingnya kejujuran, akan tetapi pembaca sudah mengetahui bahwa kejujuran penting kedudukannya dalam kehidupan manusia. Itulah nilai moral yang disampaikan dalam cerpen tersebut. 
Hal yang paling sulit dari manusia yaitu mengakui kekurangan dan keburukannya serta mengakui kelebihan dan kebaikan orang lain. Manusia cenderung lupa pada kekurangan dan keburukannya, tetapi seringkali mengetahui kekurangan dan keburukan orang lain. Padahal orang yang bijak adalah orang yang mengakui kekurangan dan keburukan serta mengakui kelebihan dan kebaikan orang lain. Jika demikian, maka hidup bermasyarakat akan menjadi aman dan tenteram. Berikut kutipannya.

Namun Tuhan itu Maha Adil. Menciptakan umatnya dengan kekurangan dan kelebihan masingmasing. Dibalik kekurangannya, Richi sesosok yang ramah, baik, sopan, suka menolong dan mau berusaha. (Ria Desy Fatmawati dalam Kado Istimewa, 2017:166).

Nilai moral pada kutipan di atas, pertama tokoh mengakui bahwa Tuhan Maha Adil. Kedua, tokoh aku mengakui kelebihan Richi walaupun banyak orang dalam cerpen menganggap Richi merupakan tokoh yang tidak baik dan banyak kekurangan. Tokoh aku memberikan contoh kepada tokoh lain, bahkan pembaca bahwa di setiap kekurangan seseorang pasti ada kelebihannya. Selain itu, di balik keburukan pasti ada kebaikannya. Jika setiap manusia menyadari hal tersebut, maka kehidupan bermasyarakat akan damai.

Bentuk nilai moral lainnya ketika seseorang dapat berpikir secara luas dan jauh untuk mencapai tujuan yang diinginkan. Selain itu ketika seseorang dapat mengambil pelajaran dari peristiwa di sekitarnya setelah melakukan perenungan-perenungan. Cerpen Kenapa Kita Harus Pintar karya Siti Zauziah Farida menguraikan hal tersebut. Berikut kutipannya.

Berfikir cerdas adalah saat kita selalu berpikir ke depan dan penuh persiapan; selalu memperhatikan sekeliling kita untuk mengumpulkan sebanyak mungkin informasi dan memanfaatkannya; selalu tahu apa yang harus kita lakukan dalam segala keadaan. (Siti Zauziah Farida dalam Kenapa Kita Harus Pintar, 2017:177).

Berdasarkan kutipan di atas, penulis cerpen menggunakan kata "kita" untuk menggambarkan wacana yang berupa nasihat. Artinya, nasihat tersebut tidak hanya untuk tokoh-tokoh yang terdapat dalam cerpen, tetapi juga kepada seluruh pembaca cerpen. Seperti yang disebutkan sebelumnya, bahwa nilai moral terdapat pada keluasan berpikir dan dapat merenungkan peristiwa-peristiwa yang terjadi di sekitar. Tujuannya sebagai modal untuk melangkah menuju depan.

Nilai moral terakhir dalam tulisan ini, yaitu menekankan pada keikhlasan menjalankan suatu hal. Banyak sekali ditemukan dalam masyarakat, bahwa seseorang masih ada pamrih atau meminta imbalan ketika melakukan pekerjaan. Cerpen Keikhlasan Hati karya Noveni Putri menceritakan hal tersebut. Berikut kutipannya.

"Adzra tak baik berpuasa mengharapkan suatu hadiah ataupun imbalan!" jelas kak Dani. (Noveni Putri dalam Keikhlasan Hati, 2017:190).

Kutipan di atas merupakan dialog antara kakak dengan adik. Kakak, yaitu Dani menasihati adiknya (Adzra) agar tidak mengharapkan hadiah atau imbalan saat menjalankan ibadah puasa. Tegasnya, 
melakukan segala sesuatu, bahkan puasa harus didasari oleh keikhlasan hati. Keikhlasan itulah yang mendorong manusia senantiasa berbuat baik, dan dalam keikhlasan dan kebaikan terdapat nilai moral.

Berdasarkan kutipan-kutipan sepuluh cerpen yang sudah disajikan dan dianalisis, nilai moral dapat ditemukan dalam banyak hal, misalnya bermanfaat untuk sesama, kasih sayang, menolong orang lain, mengakui kekurangan dan keburukan diri sendiri, mengakui kelebihan dan kebaikan orang lain, dan lain sebagainya. Nilai moral tersebut hendaknya ditanamkan kepada seseorang sejak dini sebagai pondasi menjalankan kehidupan bermasyarakat.

\section{Kesimpulan}

Nilai moral merupakan nilai-nilai kebaikan yang dimiliki oleh seseorang maupun masyarakat. Nilai moral hendaknya ditanamkan kepada seseorang sejak dini sebagai modal menjalani kehidupan. Nilai-nilai moral bisa dapat dari perilaku masyarakat atau pribadi maupun pada jenis bacaan seperti karya sastra. Salah satu karya sastra yang mudah diakses yaitu cerpen atau cerita pendek, karena tidak membutuhkan waktu lama untuk membacanya.

Kumpulan cerpen mahasiswa PGSD Universitas PGRI Adi Buana Surabaya angakatan 2013 yang terdapat dalam buku Antologi Balada Rasa dan Cerita banyak memaparkan nilai-nilai moral. Kecenderungan memasukkan nilai moral disebabkan para penulis cerpen merupakan calon guru sekolah dasar, sehingga cerpen banyak mengungkapkan nasihat-nasihat kepada anak. Nilai moral yang ditemukan diantaranya, bermanfaat untuk sesama, kasih sayang, menolong orang lain, mengakui kekurangan dan keburukan diri sendiri, mengakui kelebihan dan kebaikan orang lain, dan lain sebagainya.

\section{Daftar Acuan}

Frondizi, Risieri. 2011. Pengantar Filsafat Nilai. Cetakan III. Cetakan 1 tahun 2001. Yogyakarta: Pustaka Pelajar.

Held, Virginia. 1991. Etika Moral: Pembenaran Tindakan Sosial. Cetakan kedua. Cetakan pertama tahun 1989. Alih Bahasa: Y. Ardy Handoko. Jakarta: Erlangga.

Mahasiswa PGSD 2013 Kelas Bahasa. 2017. Antologi Puisi dan Cerpen Balada Rasa dan Cerita. Lamongan: Pagan Press.

Pramulia, Pana. 2017. Sanggit: Filosofi Pergelaran Wayang Kulit. Lamongan: Pagan Press.

Sarumpaet, Riris K. Toha. 2010. Pedoman Penelitian Sastra Anak: Edisi Revisi. Jakarta: Yayasan Pustaka Obor Indonesia.

Teew, A. 2013. Sastra dan Ilmu Sastra. Cetakan Kekempat. Cetakan Pertama tahun 1984. Bandung: Dunia

Pustaka Jaya. 